\title{
Effect of Integrated Nutrient Management on Growth and Yield of Turmeric (Curcuma longa L.) cv. Salem
}

\author{
U.B. Anuradha ${ }^{*}$, S.S. Patil, A.R. Kurubar, G. Ramesh and S. Hiregoudar \\ Department of Horticulture, University of Agricultural Sciences, Raichur-584102, \\ Karnataka, India \\ *Corresponding author
}

\begin{abstract}
A B S T R A C T
\end{abstract}
\section{Keywords}

Fresh rhizomes, turmeric, Integrated nitrogen management, Recommended dose of nitrogen,

Recommended dose of fertilizers

\section{Article Info}

Accepted:

26 December 2017

Available Online:

10 January 2018
The field experiment entitled "Effect of integrated nutrient management on growth and yield of turmeric cv. Salem" was conducted to know the effect of organic and inorganic sources of nitrogen at varied concentrations (50\% RDN and 75\% RDN) on the growth and rhizome yield of turmeric cv. Salem. The experiment was planed with eight treatment combinations replicated thrice and allotted in randomized complete block design. The experiment was laid out at Horticulture Farm, College of Agriculture, University of Agricultural Sciences, Raichur, Karnataka, India, during 2016-17. The significant differences were observed among the various treatments. Supplementation of $50 \%$ of RDN through inorganic sources remaining $50 \%$ of RDN through organic sources as pongamia cake $\left(\mathrm{T}_{7}\right)$ effected in significantly vigorous growth of the plants which resulted in higher rhizome yield (43.94 $\mathrm{t} \mathrm{ha}^{-1}$ ). It was revealed that higher fresh rhizome yield was the result of significantly higher number of mother rhizomes, primary rhizomes, secondary rhizomes and their significantly higher weight also. However, application of RDN through inorganic sources $\left(T_{1}\right)$ as per the RDF resulted in lower fresh rhizome yield coupled with low vigoured plant growth and lower yield parameters.

\section{Introduction}

Turmeric (Curcuma longa L.) is an ancient, most valuable and sacred spice of India. It is an herbaceous, perennial belonging to the family of Zingiberaceae. It contains Carbohydrates $(69.4 \%)$, fats $(5.1 \%)$, proteins $(6.3 \%)$, minerals $(3.5 \%)$, volatile oil (5.0$6.0 \%)$ and oleoresin $(7.9-10.4 \%)$ (Srinivasan et al., 2016). The documented evidence showed that turmeric is being used in daily diets of in Indian households since 6000 years as cooking spice, medicine, beauty aids, and dye. Turmeric held a place of honour in Indian traditional ayurvedic medicine. In ayurveda it was prescribed for the treatment of many medical problems such as constipation and skin diseases.

It was used as digestive aid and treatment for fever, inflammation, wounds, infections, dysentery, arthritis, injuries, trauma, jaundice and other liver problems. In Unani, turmeric is considered to be the safest herb of choice for all blood disorders since it purifies, stimulates and builds blood. 
Turmeric is being the heavy feeder which harvests abundant quantity of nutrients from soil necessitates the balance of nutrients in the soil. The continuous use of high dose of chemical fertilizers has an adverse effect not only on soil health and but also on environment.

The combined use of organic and inorganic fertilizers known as Integrated Nutrient Management not only increases the yield but also improves the physical, chemical and biological property of soil which further improves fertility, productivity and water holding capacity of soil. The organic source will help to maintain nutrient equilibrium in soils whereas, the inorganic fertilizers readily furnish nutrient which would enhance the initial growth in the crop and finally results in better growth, development and yield.

Application of increasing nitrogen rate (either from manure or synthetic fertilizers) generally promotes higher yield and dry matter accumulation. Composts and manures tend to have lower nitrogen and potassium, but higher phosphorus content. The use of manure and compost over a period of time might tend to increase tissue phosphorus, secondary and micronutrients.

Different organic manures exercise different influence in terms of growth and yield of turmeric. Use of FYM increases soil organic matter content and this has a greater residual effect (Kumaran et al., 1998). Application of different combinations of organic manures like FYM, neemcake, vermicompost also influence the growth and yield of turmeric (Sarma, 2015). Application of nitrogen fertilizer increases the plant height, number of leaves and also rhizome yield (Modupeola and Olaniyi, 2015), with this background the present experiment was conducted to study the effect of integrated nitrogen management on growth and yield of turmeric.

\section{Materials and Methods}

The experiment was carried out at Horticulture Farm, College of Agriculture, University of Agricultural Sciences, Raichur, Karnataka, India, during 2016-17. The experiment was laid out in a randomized complete block design with eight treatments replicated thrice. The following treatments were included in the study to impose on turmeric cv. Salem.

$\mathrm{T}_{1}-100 \% \mathrm{RDF}+\mathrm{FYM}$

$\mathrm{T}_{2}-75 \% \mathrm{RDN}+25 \%$ nitrogen through Neem cake

$\mathrm{T}_{3}-75 \% \mathrm{RDN}+25 \%$ nitrogen through Vermicompost

$\mathrm{T}_{4}-75 \% \mathrm{RDN}+25 \%$ nitrogen through Pongamia cake

$\mathrm{T}_{5}-50 \% \mathrm{RDN}+50 \%$ nitrogen through Neem cake

$\mathrm{T}_{6}-50 \% \mathrm{RDN}+50 \%$ nitrogen through Vermicompost

$\mathrm{T}_{7}-50 \% \mathrm{RDN}+50 \%$ nitrogen through Pongamia cake

$\mathrm{T}_{8}-50 \% \mathrm{RDN}+2 \%$ Urea as foliar spay

$(\mathrm{RDF}=150: 125: 250 \mathrm{~kg} / \mathrm{ha})$

The rhizomes were with the spacing of $45 \mathrm{~cm}$ $x 22.5 \mathrm{~cm}$. The required quantity of FYM, neem cake, pongamia cake and vermicompost for gross plot area were computed as per their $\mathrm{N}$ contents and applied in respective plots as per the treatments. Observations were recorded on growth parameters such as plant height, number of leaves per plant, number of tillers per clump and leaf area index (LAI) at 50, 100 and 150 days of crop growth, yield parameter such as number of mother 
rhizomes, number of primary rhizomes, number of secondary rhizomes, weight of mother rhizomes per clump, weight of primary rhizomes per clump and weight of secondary rhizomes per clump were observed at after harvest.

\section{Results and Discussion}

\section{Growth}

The results of the experiments conducted to supplement the RDN through organic and inorganic sources revealed that there existed the significant variation among the growth and yield of turmeric cv. Salem. Per cent of emergence $(98.00 \%$ at 45 DAP), Plant height $(122.23 \mathrm{~cm})$, Number of leaves per plant(34.40), Number of tillers per clump (5.03) and Leaf area index (3.75) exhibited significantly higher values at 150 DAP effected through the supplementation of 50 per cent RDN through inorganic and 50 per cent RDN through organic sources as pongamia cake $\left(\mathrm{T}_{7}\right)$.

However, the application of 100 per cent RDF along with FYM resulted in significantly lower per cent of emergence, plant height, number of leaves per plant, number of tillers per clump and leaf area index 87.50 (at 45DAP), $107.43 \mathrm{~cm}, 26.30,4.07$ and 3.37 at 150 DAP respectively through $\mathrm{T}_{1}$. The observations were made at vigorous growth stages of crop at 50, 100 and 150 DAP (Table 1, Fig. 1 and 2).

The height of plants increased at faster rate upto 150 days and thereafter slowed down. This trend was in good agreement with the observations of Manohar Rao et al., (2005) in turmeric. The slow growth after 150 days might be attributed to rhizomes development due to source and sink relationship. Transportation of more photosynthates from source (leaves) to sink (rhizomes). The number of leaves per tiller was significantly promoted with all the organic, inorganic and recommended dose of INM treatments (Singh, 2015).

\section{Yield}

The fresh rhizome yield per hectare was significantly high with 43.94 tonnes in $\mathrm{T}_{7}$. On the contrary $\mathrm{T}_{1}$ resulted in significantly lower fresh rhizome yield of 25.55 tonnes per hectare. However, $\mathrm{T}_{2}$ and $\mathrm{T}_{4}$ were on par with the $T_{7}$ in terms of fresh rhizome yield.

The vigorous growth of crop observed through maximum plant height, number of leaves per plant, number of tillers per clump and LAI might be attributed to higher rhizome yield from $\mathrm{T}_{7}$.

The number of tillers is an important yield attribute in turmeric, it would influence the yield and mother rhizome in turmeric as reported by Balkrishnamurthy et al., (2009) in turmeric. The results of Singh et al., (2009) in ginger and Singh (2013) in turmeric are also in confirmation with the present results.

Supplementing of RDN through $\mathrm{T}_{7}$ also effected in significantly higher number of mother rhizomes (3.67), primary rhizomes (14.13), secondary rhizomes (4.40), weight of mother rhizomes $(177.0 \mathrm{~g})$, primary rhizomes $(253.33 \mathrm{~g})$ and secondary rhizomes per clump (40.63g).

However, application of RDN (100\%) coupled with FYM resulted in significantly lower number of mother rhizomes (3.00), primary rhizomes (8.40), secondary rhizomes (2.80), weight of mother rhizomes $(125.67 \mathrm{~g})$, weight of primary and secondary rhizomes per clump (161.67g and $22.27 \mathrm{~g}$ respectively) through $\mathrm{T}_{1}$. The treatments $T_{2}$ and $T_{4}$ found to be on par with $\mathrm{T}_{1}$ in performance for above parameters (Table 2, Fig. 3 and 4). 
Table.1 Effect of integrated nitrogen management on growth of turmeric cv. Salem at different stages

\begin{tabular}{|c|c|c|c|c|c|c|c|c|c|c|c|c|c|c|c|}
\hline \multirow[t]{2}{*}{ Treatments } & \multicolumn{3}{|c|}{$\begin{array}{l}\text { Per cent of emergence } \\
(\%)\end{array}$} & \multicolumn{3}{|c|}{ Plant height(cm) } & \multicolumn{3}{|c|}{$\begin{array}{c}\text { Number of leaves per } \\
\text { plant }\end{array}$} & \multicolumn{3}{|c|}{$\begin{array}{l}\text { Number of tillers per } \\
\text { clump }\end{array}$} & \multicolumn{3}{|c|}{ Leaf Area Index } \\
\hline & $\begin{array}{c}15 \\
\text { DAP }\end{array}$ & $\begin{array}{c}30 \\
\text { DAP }\end{array}$ & $\begin{array}{c}45 \\
\text { DAP }\end{array}$ & $\begin{array}{c}\mathbf{5 0} \\
\text { DAP }\end{array}$ & $\begin{array}{l}100 \\
\text { DAP }\end{array}$ & $\begin{array}{c}150 \\
\text { DAP }\end{array}$ & $\begin{array}{c}\mathbf{5 0} \\
\text { DAP }\end{array}$ & $\begin{array}{l}100 \\
\text { DAP }\end{array}$ & $\begin{array}{c}150 \\
\text { DAP }\end{array}$ & $\begin{array}{c}50 \\
\text { DAP }\end{array}$ & $\begin{array}{c}100 \\
\text { DAP }\end{array}$ & $\begin{array}{c}150 \\
\text { DAP }\end{array}$ & $\begin{array}{c}\mathbf{5 0} \\
\text { DAP }\end{array}$ & $\begin{array}{c}100 \\
\text { DAP }\end{array}$ & $\begin{array}{c}150 \\
\text { DAP }\end{array}$ \\
\hline $\mathbf{T}_{1}$ & 13.67 & 68.88 & 87.50 & 45.04 & 99.23 & 107.43 & 8.93 & 24.57 & 26.30 & 2.20 & 3.97 & 4.07 & 1.16 & 2.30 & 3.37 \\
\hline$T_{2}$ & 43.67 & 94.33 & 97.00 & 54.02 & 110.27 & 115.57 & 11.47 & 27.00 & 32.07 & 2.53 & 4.57 & 5.03 & 1.01 & 2.1 & 3.19 \\
\hline$T_{3}$ & 27.67 & 90.00 & 92.00 & 51.00 & 104.50 & 111.43 & 9.63 & 25.13 & 28.00 & 2.30 & 4.20 & 4.93 & 0.99 & 1.87 & 3.09 \\
\hline $\mathbf{T}_{4}$ & 39.33 & 91.90 & 94.55 & 53.00 & 106.07 & 113.47 & 11.13 & 26.67 & 30.80 & 2.33 & 4.53 & 5.03 & 0.91 & 1.48 & 3.25 \\
\hline$\overline{T_{5}}$ & 35.33 & 90.02 & 92.65 & 53.65 & 105.47 & 111.67 & 10.63 & 25.63 & 28.80 & 2.43 & 4.20 & 4.97 & 1.04 & 2.18 & 3.13 \\
\hline $\mathrm{T}_{6}$ & 14.00 & 82.85 & 85.67 & 48.67 & 103.37 & 107.90 & 9.18 & 24.70 & 26.47 & 2.23 & 4.03 & 4.40 & 0.91 & 1.53 & 3.29 \\
\hline $\mathbf{T}_{7}$ & 50.33 & 96.00 & 98.00 & 57.23 & 118.93 & 122.23 & 11.57 & 29.00 & 34.40 & 2.63 & 4.97 & 5.03 & 1.11 & 2.26 & 3.75 \\
\hline $\mathrm{T}_{8}$ & 22.00 & 88.67 & 91.00 & 49.95 & 102.73 & 108.90 & 9.57 & 25.10 & 27.90 & 2.30 & 4.17 & 4.63 & 0.92 & 1.55 & 3.29 \\
\hline Mean & 30.75 & 87.83 & 92.30 & 51.57 & 106.32 & 112.33 & 10.26 & 25.96 & 29.34 & 2.37 & 4.33 & 4.76 & 1.01 & 1.91 & 3.3 \\
\hline S.Em \pm & 1.34 & 2.58 & 1.60 & 1.49 & 3.91 & 3.27 & 0.38 & 0.86 & 1.68 & 0.07 & 0.13 & 0.16 & 0.07 & 0.082 & 0.28 \\
\hline CD@5\% & 4.07 & 7.84 & $\mathbf{N S}$ & 4.53 & 11.86 & $\mathbf{N S}$ & 1.16 & 2.62 & 5.09 & 0.22 & 0.40 & 0.47 & 0.22 & 0.30 & 0.65 \\
\hline
\end{tabular}

Table.2 Effect of integrated nitrogen management on yield and yield attributes of turmeric cv. Salem

\begin{tabular}{|c|c|c|c|c|c|c|c|}
\hline \multirow[t]{2}{*}{ Treatments } & \multicolumn{3}{|c|}{ Number of Rhizomes per clump } & \multicolumn{3}{|c|}{ Weight of Rhizomes per clump (g) } & \multirow{2}{*}{$\begin{array}{c}\text { Fresh } \\
\text { Rhizome } \\
\text { Yield }\left(\mathbf{t} \mathbf{h a}^{-1}\right)\end{array}$} \\
\hline & $\begin{array}{l}\text { Mother } \\
\text { rhizomes }\end{array}$ & $\begin{array}{l}\text { Primary } \\
\text { rhizomes }\end{array}$ & $\begin{array}{c}\text { Secondary } \\
\text { rhizomes }\end{array}$ & $\begin{array}{l}\text { Mother } \\
\text { rhizomes }\end{array}$ & $\begin{array}{l}\text { Primary } \\
\text { rhizomes }\end{array}$ & $\begin{array}{c}\text { Secondary } \\
\text { rhizomes }\end{array}$ & \\
\hline $\mathbf{T}_{1}$ & 3.00 & 8.40 & 2.80 & 125.67 & 161.67 & 22.27 & 25.55 \\
\hline$T_{2}$ & 3.33 & 11.94 & 4.20 & 170.00 & 209.67 & 37.50 & 41.41 \\
\hline $\mathrm{T}_{3}$ & 3.20 & 10.23 & 3.13 & 138.67 & 192.00 & 25.53 & 32.87 \\
\hline $\mathrm{T}_{4}$ & 3.27 & 10.93 & 4.03 & 151.00 & 204.00 & 27.33 & 40.76 \\
\hline$T_{5}$ & 3.27 & 10.63 & 3.77 & 142.00 & 199.00 & 25.93 & 37.44 \\
\hline $\mathrm{T}_{6}$ & 3.13 & 9.37 & 3.00 & 135.00 & 167.67 & 23.07 & 27.73 \\
\hline $\mathrm{T}_{7}$ & 3.67 & 14.13 & 4.40 & 177.00 & 253.33 & 40.63 & 43.94 \\
\hline $\mathrm{T}_{8}$ & 3.13 & 9.90 & 3.13 & 138.00 & 180.33 & 23.93 & 27.80 \\
\hline Mean & 3.25 & 10.62 & 3.55 & 147.17 & 195.21 & 28.28 & 34.70 \\
\hline S.Em \pm & 0.10 & 0.33 & 0.31 & 4.67 & 7.15 & 2.82 & 2.47 \\
\hline CD@5\% & 0.29 & 1.00 & 0.93 & 14.18 & 21.69 & 8.54 & 7.50 \\
\hline
\end{tabular}


Fig.1 Per cent of emergence of turmeric cv. Salem at 15, 30 and 45 days after planting as influenced by the application of recommended dose of nitrogen through inorganic and organic sources

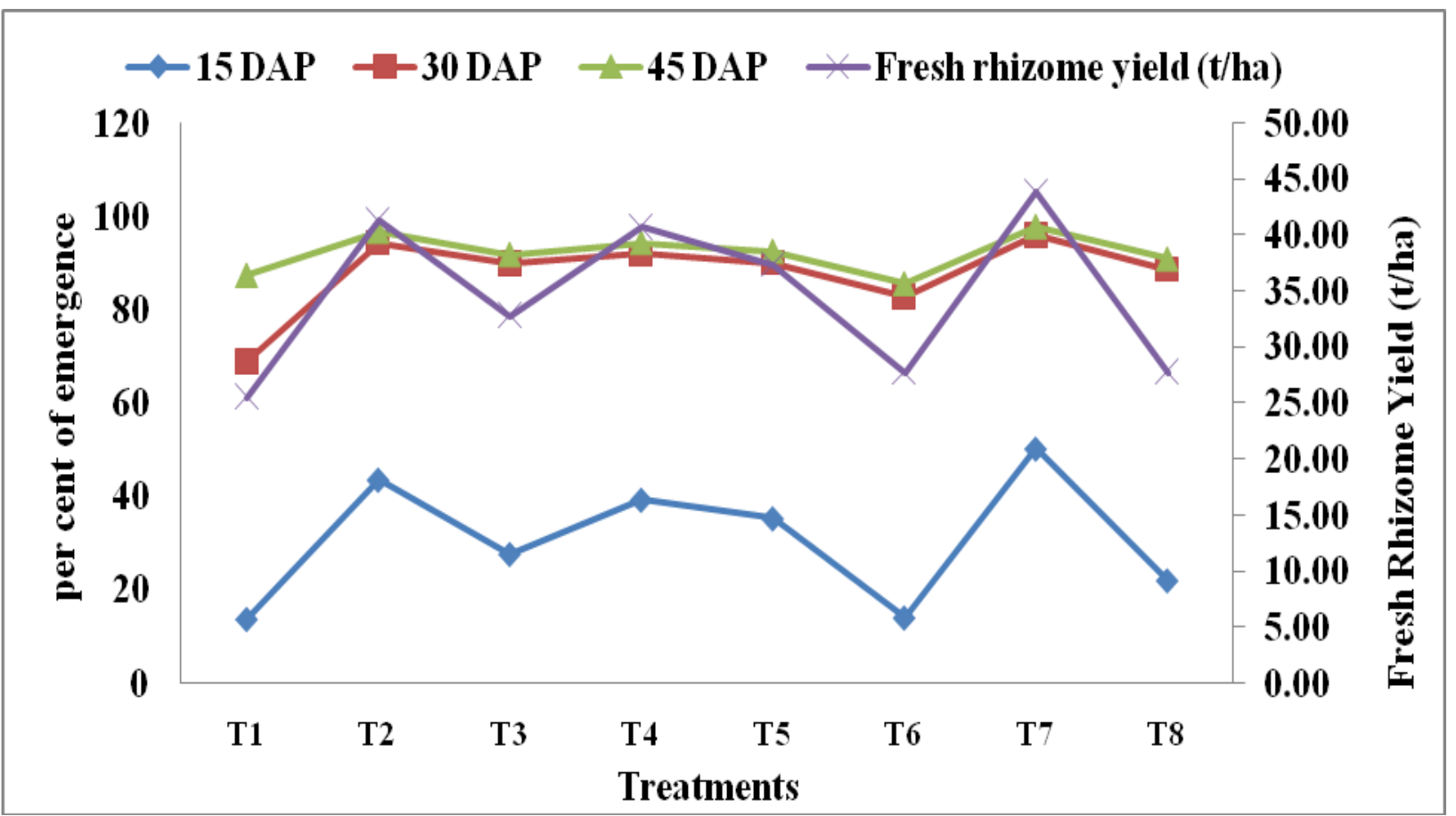

Fig.2 Plant height of turmeric cv. Salem at different growth stages as influenced by the application of recommended dose of nitrogen through inorganic and organic sources

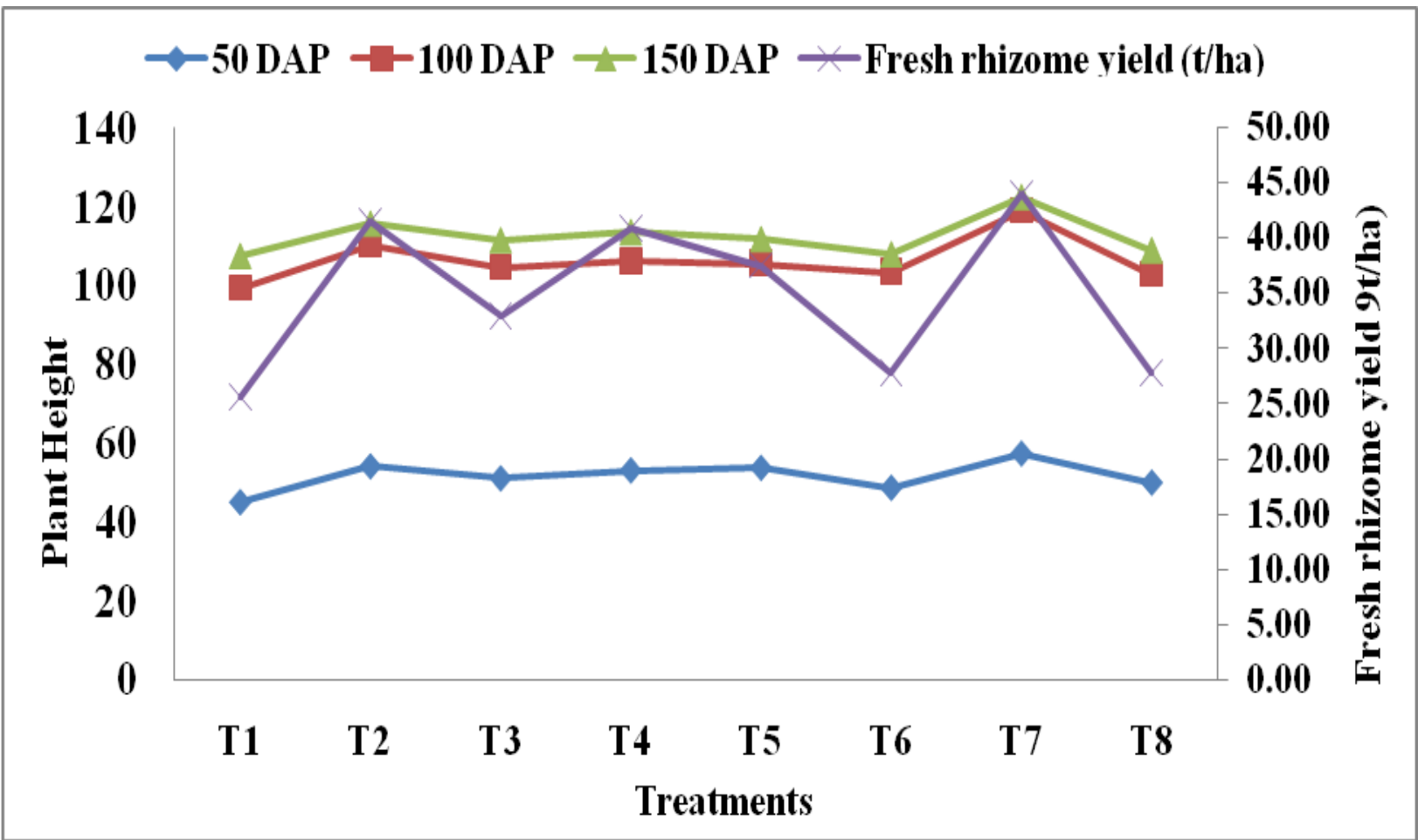


Fig.3 Number of fresh rhizomes per clump of turmeric cv. Salem as influenced by the application of recommended dose of nitrogen through inorganic and organic sources

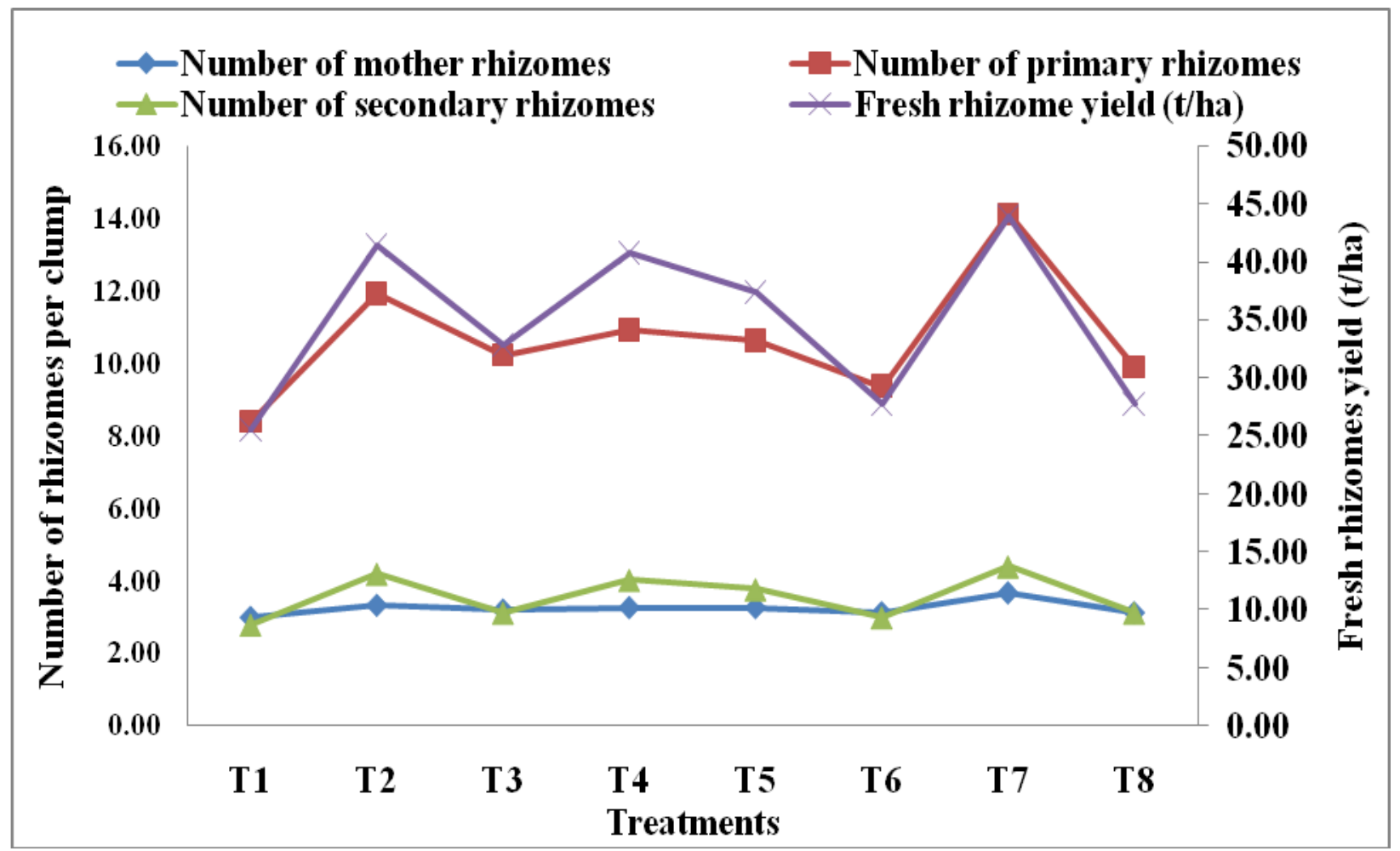

Fig.4 Weight of fresh rhizomes per clump of turmeric cv. Salem as influenced by the application of recommended dose of nitrogen through inorganic and organic sources

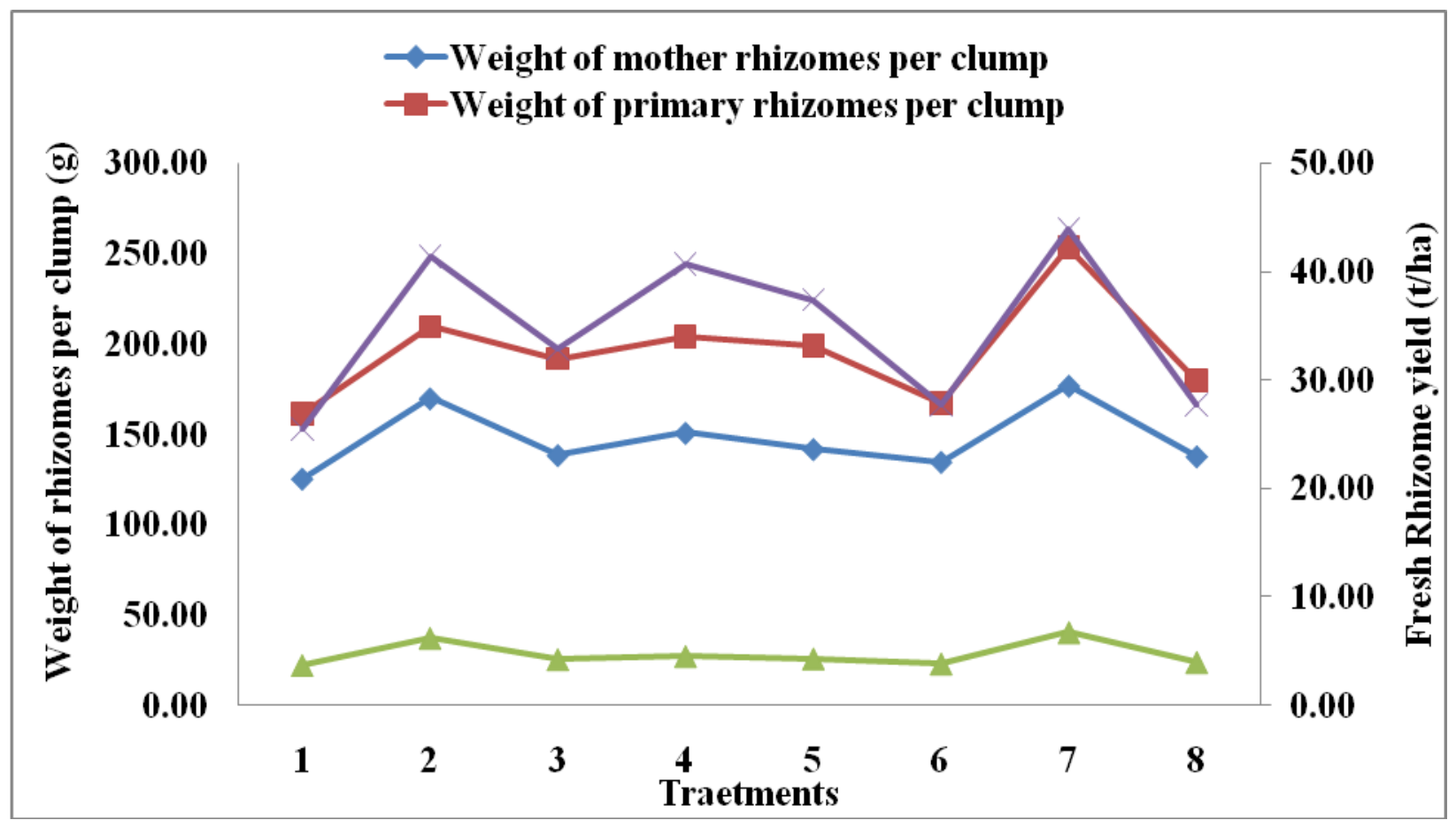


Significantly higher fresh rhizome yield obtained from $\mathrm{T}_{7}$ might be due to the effect of maximum number of mother rhizomes, primary rhizomes, secondary rhizomes, weight of mother rhizomes per clump, weight of primary and secondary rhizomes per clump also the higher nutrient status of pongamia cake preferably high $\mathrm{N}$ and $\mathrm{K}$ content compared to other organic sources such as neemcake and vermicompost. Especially $\mathrm{N}$ and $\mathrm{K}$ are two important nutrients for boosting the growth and yield of turmeric. Nitrogen is involved in chlorophyll synthesis and it influences stomatal conductance and photosynthetic efficiency. $\mathrm{N}$ is responsible for 26 to 41 per cent of crop yields. K plays catalytic roles in the plant rather than becoming an integral part of plant components. It regulates the permeability of cell walls and activities of various mineral elements as well as neutralizing physiologically important organic acids. Banafor et al., 1995 and Sugtto et al., 1995 reported that with the increase in $\mathrm{K}$ levels growth, leaves number, tillers number and rhizome yield increased. The mother rhizomes, primary rhizomes and secondary rhizomes and their increased number do have direct impact on the weight and yield of fresh rhizomes. Normally early emergence of rhizomes through soil after the planting results in higher yield of turmeric which might be the contributing factors towards maximum fresh rhizome yield effected through $\mathrm{T}_{7}$.

It was generally observed that the application of RDN through varied combinations of organic and inorganic sources using vermicompost, neem cake and pongamia cake have resulted in comparatively higher yield of rhizomes per hectare affected due to growth and yield parameters. Application of organic manures increased the nutrient availability, improved the physical conditions of the soil, and increased the yield (Sadanandan and
Hamza, 1998). Plant height, leaves number, finger weight, finger size and turmeric yield were influenced by $\mathrm{N}$ application and also found that with the increment of $\mathrm{N}$ levels, all the yield contributing parameters increased progressively (Haque et al., 2007). Pronounced yield improvement in organic treatment might be due to sustained availability of nitrogen throughout the growing phase and also due to enhanced photosynthates and effective translocation of them to the sink i.e., rhizome, while at lower fertility levels plants remained stunted resulting in decreased yield. The beneficial effect of organics was obtained in many crops (Singh, 2015).

\section{Acknowledgement}

To the University of Agricultural Sciences, College of Agriculture Raichur for providing research facilities is gratefully acknowledged.

\section{References}

Balakrishnamurty, G., Kumar, K. R. and Prabu, T., 2009. Standardization of organic manures and bioregulants for organic production of turmeric (Curcuma longa L.). In production technology for organic spices (Ed. M Tamil Selvan, Homey Cheriyan, K. Manoj, Kumar and Babulal Meena). Publish, Director, Directorate of Arecanut and Spices Development, Calicut, Kerala, India. PP 123-130.

Banafar, R. B. S. and Tiwari, R. J., 1995. Response of turmeric to potassium application in medium black soils of Madhya Pradesh. Crop Res., 10 (1): 9395.

Haque, M. M., Rahman, A. K. M. M., Ahmed, M., Masud, M. M. and Sarker, M. M. R., 2007. Effect of nitrogen and potassium on the yield and quality of turmeric in Hill Slope. Int. J. Sustain. 
Crop Prod., 2(6):10-14.

Kumaran, S., Natranjan, S. and Thamburaj, S. 1998. Effect of organic and inorganic fertilizers on growth, yield and quality of tomato. South Indian Journal of Hort., 46 (3 \& 4): 203-205.

Manohar R, A., Venkata R, P., Narayana R, Y. and Reddy, M. S. N. 2005. Effect of organic and inorganic manorial combination on growth, yield and quality of turmeric (Curcuma longa L.). J. Plantn. Crops, 33 (3): 198-205.

Modupeola, T. O. and Olaniyi, J. O., 2015. Effects of nitrogen $(\mathrm{N})$ fertilizer and plant spacing on the growth and rhizome yield of turmeric (Curcuma Longa L.) in Ibadan South-West Nigeria. Int. J. of Plant Sci. and Eco, 1(4):149-154.

Sadanandan, A. K. and Hamza, S., 1998. Effect of organic farming on nutrient uptake, yield and quality of ginger (Zingiber officinale).Water and nutrient management for sustainable production and quality of spices, Madikeri, Karnataka: 9-94.

Sarma, I., Phukon, M. And Roop, B., 2015. Effect of organic manure, vermicompost and neemcake on growth, yield and profitability of turmeric (Curcuma longa L.) variety-
Megha Turmeric-1. Asian journal of bio science. 10(2): 133-137.

Singh, S. P., 2013. Response of different combination of organic manures for production of turmeric (Curcuma longa L.). Journal of Eco-friendly Agriculture, 8:35-38.

Singh, S. P., 2015. Nutrient supplementation through organic manures for growth and yield of ginger (Zingiber officinale Rose.). Journal of Eco-friendly Agriculture. 10(1): 28-31.

Singh, S.P., Chaudhary, R. and Mishra, A.K., 2009. Effect of different combination of organic manures on growth and yield of ginger (Zingiber officinale Rose). Journal of Eco-friendly Agriculture, 4: 2224.

Srinivasan, V., Thankamani, C. K., Dinesh, R., Kandiannan, K., Zachariah, T. J., Leela, N. K., Hamaz, S., Shajina, O. and Ansha, O., 2016. Nutrient management system in turmeric: Effects on soil quality, rhizome yield and quality. Industrial crops and products.85: 241250.

Sugtto, Y. and Ma fluchah. 1995. Influence of rates of farmyard manure and $\mathrm{KCI}$ on growth, yield and quality of young ginger rhizome. A grivita. 18(2): 67-73

\section{How to cite this article:}

Anuradha, U.B., S.S. Patil, A.R. Kurubar, G. Ramesh and Hiregoudar, S. 2018. Effect of Integrated Nutrient Management on Growth and Yield of Turmeric (Curcuma longa L.) cv. Salem. Int.J.Curr.Microbiol.App.Sci. 7(01): 3196-3203.

doi: https://doi.org/10.20546/ijcmas.2018.701.381 